\title{
PENINGKATKAN HASIL BELAJAR MATEMATIKA DENGAN TIPE TWO-STAY TWO-STRAY SISWA KELAS XI TKJ 2 SMKN 1 BANGIL
}

\author{
SUJIYONO \\ SMK Negeri 1 Bangil Kabupaten Pasuruan \\ e-mail: sujiyono.196607@gmail.com
}

\begin{abstract}
ABSTRAK
Pada pembelajaran matematika pada kompetensi dasar menghitung luas permukaan dan volume bangun ruang sering menjadi masalah, khusunya pada siswa kelas XI Teknik Komputer Jaringan 2 di SMK Negeri 1 Bangil. Diketahui bahwa masalah utama dari pembelajaran matematika, kemampuan menghitung luas permukaan dan volume bangun ruang rendah. Berdasarkan permasalahan tersebut peneliti mencoba menghadirkan penggunaan model pembelajaran tipe TS-TS (Two Stay Two Stray) untuk lebih mudah menemukan dan menerapkan perolehan konsep, sehingga peneliti menentukan berdasar atas rumusan masalah di atas, maka tujuan dilaksanakannya penelitian ini adalah untuk meningkatkan prestasi belajar bangun ruang pada siswa kelas XI Teknik Komputer Jaringan 2 SMK Negeri 1 Bangil Kabupaten Pasuruan dengan menggunakan model pembelajaran tipe TS-TS (Two Stay Two Stray). Dari Permasalahan itu peneliti memperoleh data hasil observasi dan refleksi. Berdasarkan data observasi diperoleh peningkatan prestasi belajar siswa pada siklus I terdapat 26 siswa (72\%) mencapai nilai ketuntasan yaitu $\geq 70$ dengan rata-rata kelas 73,89 sedangkan pada sikius II diperoleh 34 siswa $(94,4 \%)$ mencapai nilai ketuntasan yaitu $\geq 70$ dengan rata-rata kelas 82,22. Dari hasil perbaikan pembelajaran yang dilaksanakan oleh peneliti maka dapat ditarik kesimpulan bahwa penggunaan Model Pebelajaran Tipe TS-TS (Two Stay Two Stray) dapat meningkatkan prestasi belajar siswa kelas XI Teknik Komputer Jaringan 2 SMK Negeri 1 Bangil. Hal ini menunjukkan bahwa Model Pebelajaran Tipe TS-TS (Two Stay Two Stray) yang digunakan peneliti terbukti dapat meningkatkan Prestasi Belajar siswa kelas XI Teknik Komputer Jaringan 2.
\end{abstract}

Kata kunci : Bangun Ruang, Two Stay Two Stray, Hasil Belajar

\section{ABSTRACT}

In learning mathematics, the basic competence of calculating surface area and volume is often a problem, especially for students of class XI Computer Network Engineering 2 at SMK Negeri 1 Bangil. It is known that the main problem of learning mathematics, the ability to calculate surface area and volume of geometric figures is low. Based on these problems the researchers tried to present the use of the TS-TS (Two Stay Two Stray) type learning model to more easily find and apply the concept acquisition, so the researchers determined based on the formulation of the problem above, then the purpose of this research is to improve learning achievement in building space. in class XI Computer Network Engineering 2 SMK Negeri 1 Bangil Pasuruan Regency using the TS-TS (Two Stay Two Stray) type of learning model. From the problem, the researcher obtained data from observations and reflections. Based on observational data, it was found that there was an increase in student achievement in the first cycle, there were 26 students (72\%) achieving a completeness score that was $>70$ with a class average of 73.89 while in Cycle II, 34 students $(94.4 \%)$ achieved a completeness score, namely $>70$ with a class average of 82.22 . From the results of learning improvements carried out by researchers, it can be concluded that the use of the TS-TS (Two Stay Two Stray) Type Learning Model can improve student achievement in class XI Computer Network Engineering 2 SMK Negeri 1 Bangil. This shows that the TS-TS (Two Stay Two Stray) Type Learning Model used by researchers has proven to be able to improve the learning achievement of students in class XI Computer Network Engineering 2.

Keywords: Build Space, Two Stay Two Stray, Learning Outcomes 


\section{PENDAHULUAN}

Matematika merupakan salah satu pelajaran yang sulit bagi sebagian siswa. Kesulitan siswa dalam memahami matematika bisa disebabkan oleh berbagai hal, diantaranya kurang tepatnya guru dalam memilih model pembelajaran yang diterapkan dalam kegiatan belajar mengajar. Selain itu penguasaan materi menjadi landasan pokok guru dalam mengajar, penguasaan materi menjadi aspek penting yang perlu dimiliki oleh setiap guru karena berkaitan langsung pada pemahaman siswa terhadap materi. Jika mengacu pada standar isi mata pelajaran matematika (Permendiknas No. 22, Tahun 2007) tujuan pelajaran matematika di SMK adalah dapat membantu siswa dalam memahami konsep-konsep matematika dalam keterkaitan dan penerapannya untuk menyelesaikan masalah dalam kehidupan sehari-hari dan teknolog, serta menggunakan pengetahuan dasar matematika sebagai landasan dalam pengembangan kompetensi di masing-masing bidang keahlian. Berkaitan dengan hal tersebut, maka perlu diterapkan suatu model pembelajaran yang dapat membangkitkan dan melibatkan keaktifan siswa dalam kegiatan belajar mengajar. Karena dengan siswa yang aktif, materi dalam matematika akan lebih mudah dipahami. Salah satu materi dalam matematika yang harus dikuasai siswa adalah materi bangun ruang. Materi ini memerlukan pemahaman yang cukup mendalam mengenai rusuk, sisi, luas permukaan dan volume dari bangun ruang. Oleh karena itu model pembelajaran kooperatif tipe Two Stay Two Stray bisa menjadi solusi permasalahan tersebut.

Berdasarkan hasil observasi, pembelajaran yang diterapkan di tempat penelitian masih menggunakan pembelajaran yang konvensional. Hasil belajar masih jauh dari kata memuaskan. Hal tersebut dilihat dari rata-rata kelas yang tidak mencapai KKM. Slavin (2009: 4) mengemukakan bahwa pembelajaran kooperatif merujuk pada berbagai macam metode pengajaran dimana siswa bekerja pada kelompok-kelompok kecil untuk saling membantu satu sama lainnya dalam mempelajari suatu materi pelajaran. Hal ini bertujuan agar proses pembelajaran tidak didominasi oleh satu orang, melainkan semua anggota kelompok mempunyai kewajiban dan tanggung jawab yang sama dalam menyelesaikan masalah kelompoknya. Sehingga proses pembelajaran yang terjadi dapat mengaktifkan semua siswa dan lebih berpusat pada siswa. Model pembelajaran kooperatif Two Stay Two Stray menurut Ika Berdiati (2010: 92) adalah model pembelajaran Two Stay Two Stray atau dua tinggal dua bertamu merupakan bagian dari pembelajaran koopertif yang memberi pengalaman kepada siswa untuk berbagi pengetahuan baik di dalam kelompok maupun dalam kelompok lainnya. Dalam diskusi berkelompok siswa dituntut berperan sacara aktif untuk memecahkan suatu masalah secara bersama-sama dengan teman sekelompoknya. Setelah itu hasil dari diskusi kelompok akan dicocokkan dengan jawaban dengan kelompok lain yang diperoleh dari dua teman mereka yang bertamu ke kelompok lain. Menurut (Lie, 2005:61) teknik Two Stay Two Stray merupakan salah satu teknik dalam pembelajaran kooperatif yang memberi kesempatan kepada kelompok untuk membagikan hasil dan informasi dengan kelompok lain. Pada teknik ini setiap kelompok mendapatkan materi yang berbeda. Setelah selesai berdiskusi pada kelompok masing-masing, perwakilan setiap kelompok akan mengunjungi kelompok lain sehingga pada akhirnya setiap kelompok akan menguasai materi pembelajaran secara utuh. Oleh karena itu peneliti tertarik untuk melakukan penelitian yang berjudul "Peningkatkan Hasil Belajar Bangun Ruang Melalui Model Pebelajaran Tipe Two Stay Two Stray Pada Siswa Kelas XI Teknik Komputer Jaringan 2 SMK Negeri 1 Bangil Kabupaten Pasuruan.

Berdasarkan latar belakang di atas dapat dikaji permasalahan yang dapat dirumuskan adalah "Apakah model pembelajaran tipe Two Stay Two Stray dapat meningkatkan hasil belajar bangun ruang pada siswa kelas XI Teknik Komputer Jaringan 2 SMK Negeri 1 Bangil Kabupaten Pasuruan". Adapun maksud penulis mengadakan penelitian tindakan kelas ini diharapkan dapat berguna bagi: (1) Sekolah, memberikan informasi tetang pengaruh Model Pembelajaran Two Stay Two Stray) dalam meningkatkan prestasi belajar bangun ruang pada mata pelajaran matematika. (2) Guru, sebagai bahan pertimbangan dalam menentukan metode pembelajaran yang dapat memberikan manfaat bagi siswa. (3) Siswa, dapat meningkatkan 
motivasi belajar dan melatih sikap sosial untuk saling peduli terhadap keberhasilan siswa lain dalam mencapai tujuan belajar.

\section{METODE PENELITIAN}

Subyek dalam penelitian ini adalah siswa kelas XI Teknik Komputer Jaringan 2 SMK Negeri 1 Bangil Kabupaten Pasuruan Provinsi Jawa Timur yang berjumlah 36 siswa. Peneliti memilih kelas ini karena peneliti pengampu mata pelajaran matematika di kelas ini dan berdasarkan hasil ulangan harian terakhir, kelas XI Teknik Komputer Jaringan 2 mempunyai nilai dengan katagori rendah. Jenis penelitian ini merupakan Penelitian Tindakan Kelas (Classroom Action Research). Menurut Arikunto (2013:130) penelitian tindakan kelas merupakan suatu pencermatan terhadap kegiatan yang sengaja dimunculkan,dan terjadi dalam sebuah kelas. Penelitian ini terdiri dari dua siklus, siklus I dilaksanakan pada tanggal 7 dan 9 Oktober 2013 sedangkan siklus II dilaksanakan pada tanggal 21 dan 23 Oktober 2013. Dengan menggunakan model pembelajaran tipe Two Stay Two Stray, model pembelajaran tipe Two Stay Two Stray adalah salah satu model pembelajaran kooperatif yang memberikan kesempatan kepada siswa untuk saling berinteraksi dan bekerjasama dalam kelompok heterogen yang terdiri dari 4 siswa dalam setiap kelompok, dimana dua orang siswa tinggal di kelompok dan dua orang siswa bertamu ke kelompok lain. Dua orang yang tinggal bertugas memberikan informasi kepada tamu tentang hasil kelompoknya, sedangkan yang bertamu bertugas mencatat hasil kelompok yang dikunjunginya.

Teknik pengumpulan data penelitian ini: observasi aktivitas siswa dan guru, angket respon siswa, test akhir belajar. Sedangkan instrumen yang digunakan dalam penelitian ini adalah: rencana pelaksanaan pembelajaran (RPP), lembar kerja siswa (LKS), soal tes hasil belajar, lembar observasi aktivitas siswa dan guru, lembar angket respon siswa. Untuk menentukan nilai ulangan atau tes hasil belajar dari penelitian ini di tiap siklusnya, peneliti menggunakan rumusyang sudah ditentukan. Sedangkan untuk ketuntasan belajar, ada dua kategori ketuntasan belajar yaitu secara perorangan dan secara klasikal. Berdasarkan petunjuk pelaksanaan belajar mengajar kurikulum 1994 (Depdikbud, 1994), yaitu seorang siswa telah tuntas belajar bila telah mencapai skor $70 \%$ atau nilai 70 , dan kelas disebut tuntas belajar bila di kelas tersebut terdapat $80 \%$ yang telah mencapai daya serap lebih dari atau sama dengan $70 \%$. Desain atau rancangan penelitian yang digunakan dalam penelitian ini dapat digambarkan sebagai berikut:

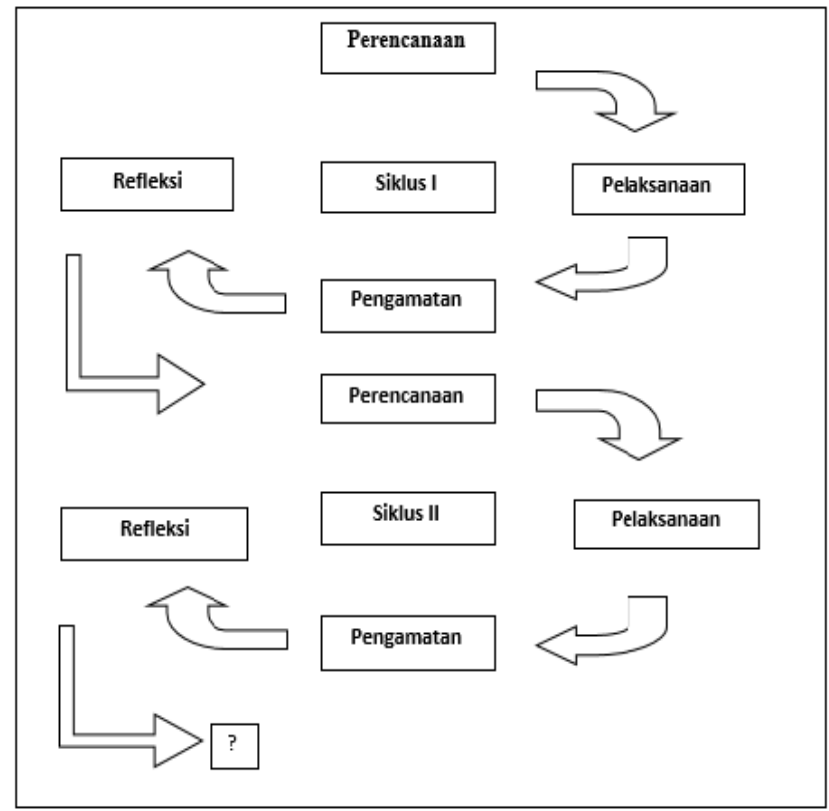

Gambar 1. Model Penelitian Tindakan 


\section{HASIL DAN PEMBAHASAN}

\section{Hasil}

Menurut (Sudjana, 2005:111) hasil belajar adalah bentuk tingkah laku yang dimiliki siswa setelah menyelesaikan pengalaman belajar. Bentuk tingkah laku sebagai hasil belajar dapat berupa memberi reaksi terhadap rangsangan, asosiasi verbal, mengemukakan konsep, prinsip, dan memecahkan masalah. Hasil belajar biasanya diperoleh setelah siswa dinyatakan berhasil dalam suatu penilaian yang dilkukan pada akhir pembelajaran. Model pembelajaran kooperatif tipe Two Stay Two Stray memiliki tujuan yang sama dengan pendekatan pembelajaran kooperatif, yaitu siswa di ajak untuk bergotong royong dalam menemukan suatu konsep. Penggunaan model pembelajaran kooperatif tipe Two Stay Two Stray akan mengarahkan siswa untuk aktif, baik dalam berdiskusi, tanya jawab, mencari jawaban, menjelaskan dan juga menyimak materi yang dijelaskan oleh teman (http://penelitiantindakankelas.blogspot.com). Proses pembelajaran dengan menggunakan model pembelajaran kooeratif tipe Two Stay Two Stray pada siklus I terdiri dari dua pertemuan. Pertemuan pertama membahas materi luas permukaan prisma tegak dan luas permukaan limas tegak beraturan, dan pada pertemuan kedua pemberian tes hasil belajar.

\section{Kegiatan Siklus I}

Pada siklus I pertemuan pertama proses yang dilakukan peneliti meliputi perencanaan, pelaksanaan, pengamatan, dan refleksi. Adapun masing-masing kegiatan dijabarkan sebagai berikut. (a) Perencanaan, pada tahap perencanaan peneliti menyusun dan menyiapkan instrumen penelitian antara lain menyusun RPP, Lembar Kerja Siswa , lembar observasi untuk mengamati aktivitas siswa dan guru dan soal tes hasil belajar siklus I beserta pedoman penskoran. (b) Pelaksanaan Tindakan, pelaksanaan kegiatan belajar mengajar untuk silkus I pertemuan pertama dilaksanakan pada tanggal 7 Oktober 2013 di kelas XI Teknik Komputer Jaringan 2 SMK Negeri 1 Bangil dengan jumlah 36 siswa. Dalam hal ini peneliti sebagai guru mata pelajaran di kelas tersebut. Adapun proses belajar mengajar sebagai berikut: Guru mengawali dengan mengucapkan salam, berdoa, mengabsen kehadiran siswa, memberi penjelasan mengenai pentingnya materi yang akan dipelajari dan menyampaikan tujuan pembelajaran. Kemudian guru memotivasi siswa dengan mengaitkan materi yang akan dipelajari dalam kehidupan sehari-hari. Selanjutnya guru menyampaikan materi secara garis besar tentang materi yang akan dipelajari. Setelah itu guru membagi siswa menjadi 9 (sembilan) kelompok yang masing-masing beranggotakan 4 siswa. Kemudian siswa diminta berkumpul dengan kelompoknya masing-masing. Setelah itu guru membagikan LKS kepada setiap kelompok ,kemudian meminta siswa untuk mengidentifikasi dan memecahkan permasalahan yang ada. Setelah selesai mendiskusikan persoalan yang ada di LKS, dua siswa dari masingmasing kelompok meninggalkan kelompoknya untuk bertamu ke kelompok lain. Sedangkan siswa yang tinggal dalam kelompok bertugas menyampaikan hasil kerja mereka kepada siswa yang datang mengunjungi kelompoknnya. Setelah memperoleh informasi dari siswa yang tinggal, siswa mohon diri untuk kembali ke kelompok masing-masing dan melaporkan hasil kerjanya serta mencocokkan dan membahasnya. Selanjutnya guru meminta salah satu kelompok untuk mempresentasikan hasil diskusinya sementara kelompok lain menanggapi. Diakhir pembelajaran guru mengevaluasi pembelajaran dengan memberikan kesimpulan dan penguatan dari materi yang telah dipelajari pada saat itu. Dan selama proses pembelajaran berlangsung, pengamatan jalannya pembelajaran dengan menggunakan lembar observasi siswa dan guru.

Pada pertemuan kedua tanggal 9 Oktober 2013 dilaksanakan tes hasil belajar siklus I. Tes hasil belajar dikerjakan secara individu dengan 5 soal uraian dalam waktu 70 menit. Tes dilakukan untuk mengetahui sejauh mana keberhasilan pembelajaran dengan menggunakan model pembelajara kooperatif tipe Two Stay Two Stray ini. Berikut disajikan prestasi belajar siklus I seperti pada gambar 2: 


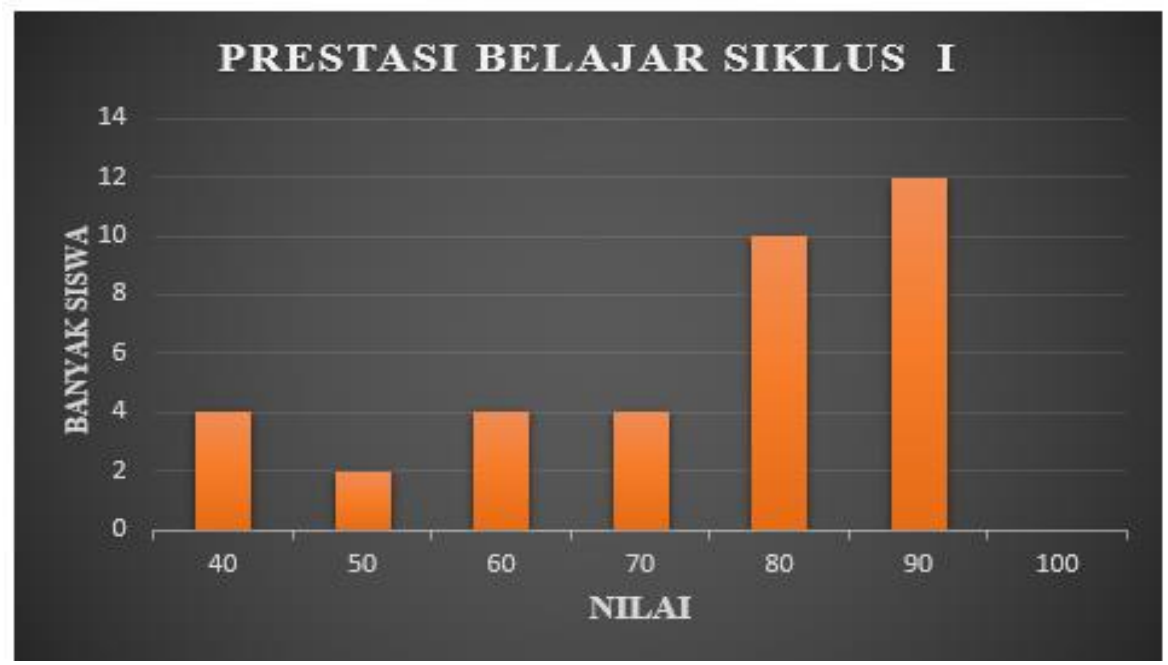

Gambar 2. Prestasi Belajar Siklus I

(c) Refleksi, kegiatan refleksi dalam siklus I ini merupakan evaluasi terhadap perencanaan, pelaksanaan dan observasi pembelajaran matematika kompetensi dasar menghitung luas permukaan dan volume bangun ruang. Pada kegiatan ini ditemukan : (1) Aktivitas belajar siswa belum optimal sehingga diperlukan petunjuk yang lebih jelas dan pengawasan guru lebih intensif. Hal ini terbukti dari hasil pengamatan aktivitas siswa selama proses pembelajaran yaitu terdapat beberapa siswa yang aktif, sedangkan siswa yang lain masih belum menunjukan peningkatan aktifitasnnya.(2) Prestasi Belajar atau hasil tes belajar siswa dalam kegiatan siklus ini masih belum maksimal, sesuai dengan tujuan belajar yang diharapkan sehingga guru harus melakukan perbaikan ulang. Dari data hasil prestasi belajar ditemukan 26 siswa (72\%) dari 36 siswa kelas XI Teknik Komputer Jaringan 2 memperoleh nilai 70 keatas memenuhi target KKM yang dinyatakan tuntas, sedangkan 10 siswa (28\%) dari seluruh siswa kelas tersebut masih memperoleh nilai dibawah 70 dinyatakan belum tuntas. Hal tersebut disajikan pada gambar 3 di bawah ini.

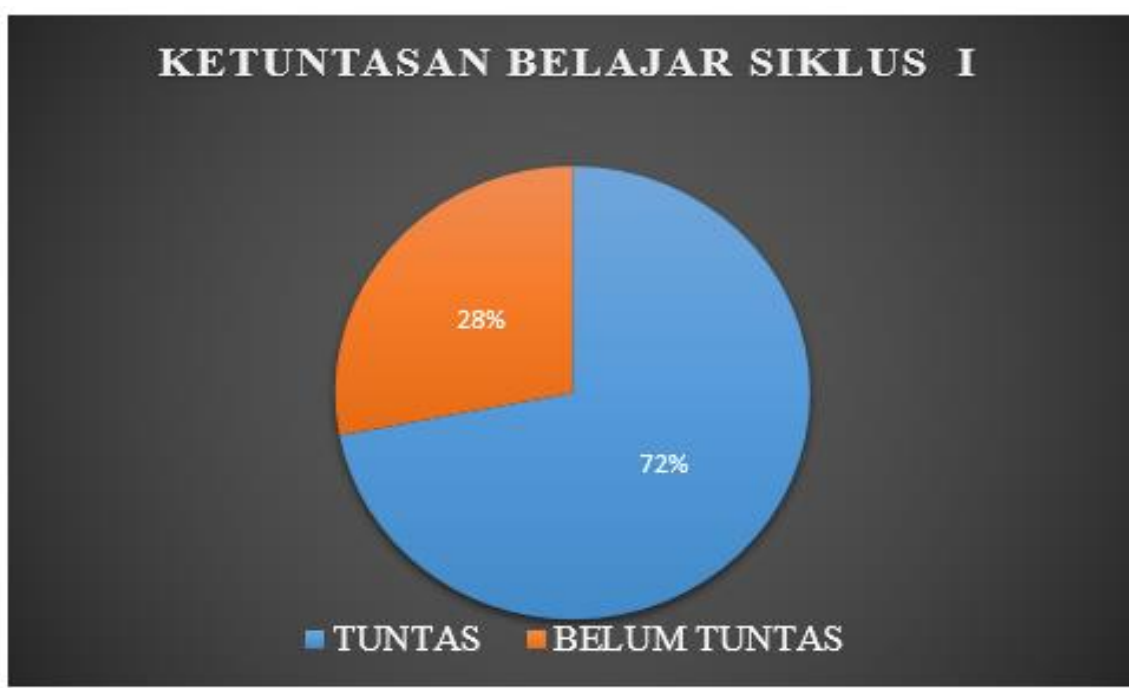

Gambar 3. Ketuntasan Belajar Siklus I

\section{Kegiatan Siklus II}

Pada kegiatan siklus II ini pada dasarnya sama dengan tindakan yang dilakukan pada siklus I namun perhatian dan pembimbingan peneliti terhadap proses pembelajaran siswa lebih efektif dan efisien.

Kegiatan siklus II pertemuan pertama dilaksanakan pada tanggal 21 Oktober 2013. Diawali dengan pendahuluan, pelaksanaan pembelajaran dimulai dengan mengucapkan salam, berdoa, 
presensi kelas oleh peneliti sebagai guru kemudian menjelaskan tujuan pembelajaran dan mengingatkan cara penilaian yang akan digunakan. Memberikan apersepsi dengan cara mengaitkan materi pelajaran dengan contoh kehidupan sehari-hari. Motivasi dilakukan peneliti untuk memberikan semangat dalam pembelajaran pertemuan ini dan menjelaskan langkahlangkah kegiatan pembelajaran. Pada kegiatan Inti, peneliti menjelaskan singkat materi tentang luas permukaan dan volume bangun ruang dari buku sumber. Setelah itu guru membagi siswa menjadi 9 (sembilan) kelompok yang masing-masing beranggotakan 4 siswa. Kemudian siswa diminta berkumpul dengan kelompoknya masing-masing. Setelah itu guru membagikan LKS kepada setiap kelompok ,kemudian meminta siswa untuk mengidentifikasi dan memecahkan permasalahan yang ada. Setelah selesai mendiskusikan persoalan yang ada di LKS, dua siswa dari masing-masing kelompok meninggalkan kelompoknya untuk bertamu ke kelompok lain. Sedangkan siswa yang tinggal dalam kelompok bertugas menyampaikan hasil kerja mereka kepada siswa yang datang mengunjungi kelompoknnya. Setelah memperoleh informasi dari siswa yang tinggal, siswa mohon diri untuk kembali ke kelompok masing-masing dan melaporkan hasil kerjanya serta mencocokkan dan membahasnya. Selanjutnya guru meminta salah satu kelompok untuk mempresentasikan hasil diskusinya sementara kelompok lain menanggapi. Diakhir pembelajaran guru mengevaluasi pembelajaran dengan memberikan kesimpulan dan penguatan dari materi yang telah dipelajari pada saat itu. Dan selama proses pembelajaran berlangsung, pengamatan jalannya pembelajaran dengan menggunakan lembar observasi siswa dan guru. Setelah selesai diskusi diadakan presentasi hasil kerja kelompok, kemudian guru memberikan pembahasan dan penguatan hasil presentasi siswa. Disesi penutup pembelajaran pertemuan ini guru bersama-sama siswa menyimpulkan materi pembelajaran, kemudian guru melakukan refleksi dengan menanyakan kesan-kesan siswa terhadap pembelajaran yang telah diikuti. Guru memberikan tugas untuk mempelajari materi yang sudah dipelajari untuk pertemuan berikutnya.

Selanjutnya kegiatan siklus II pertemuan kedua pada tanggal 23 Oktober 2013 dilaksanakan tes hasil belajar siklus II, dengan pemberian 5 soal yang berupa soal uraian dengan waktu 70 menit dilakukan secara individu, yang diikuti oleh 36 siswa kelas XI Teknik Komputer Jaringan 2 SMK Negeri 1 Bangil. Tes hasil belajar dilakukan untuk mengetahui sejauh mana keberhasilan pembelajaran dengan menggunakan model pembelajaran tipe Two Stay Two Stray ini. Adapun nilai tes hasil belajar yang dilaksanakan pada siklus II disajikan pada gambar 4 berikut ini.

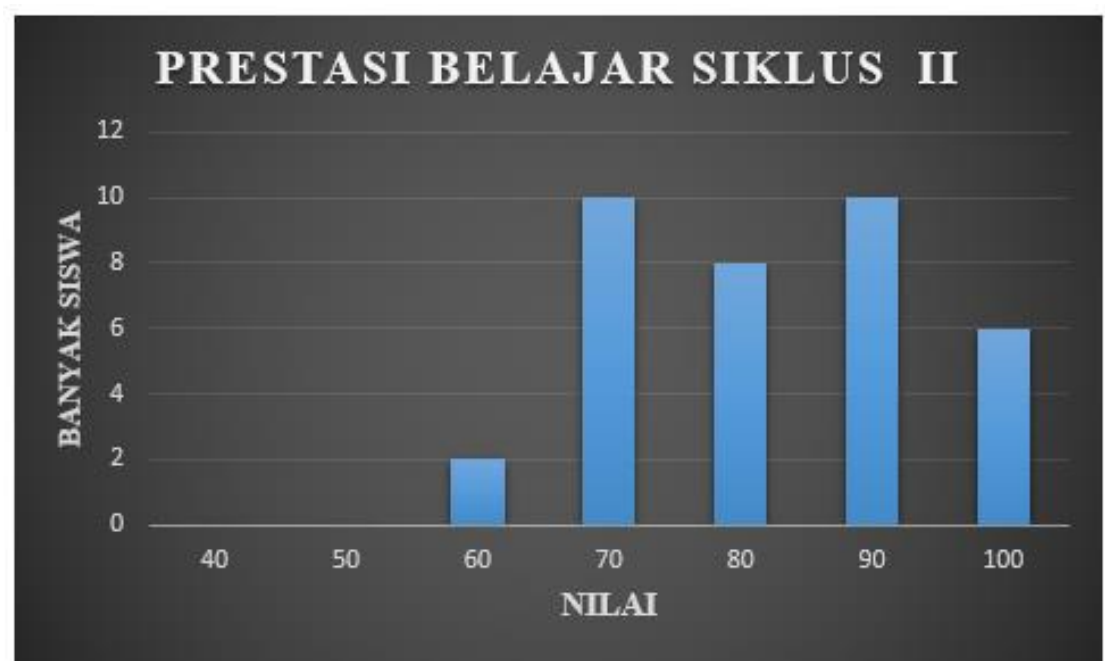

Gambar 4. Prestasi Belajar Siklus II

Dari data nilai tes hasil belajar pada siklus II pada tanggal 23 Oktober 2013 ditemukan 34 siswa $(94,4 \%)$ dari 36 siswa kelas XI Teknik Komputer Jaringan 2 memperoleh nilai 70 keatas yang dinyatakan tuntas, sedangkan 2 siswa $(5,6 \%)$ dari seluruh siswa kelas tersebut 
masih memperoleh nilai dibawah 70 dinyatakan belum tuntas dengan rata-rata 82,22. Data tersebut bisa dilihat pada gambar 5 di bawah ini.

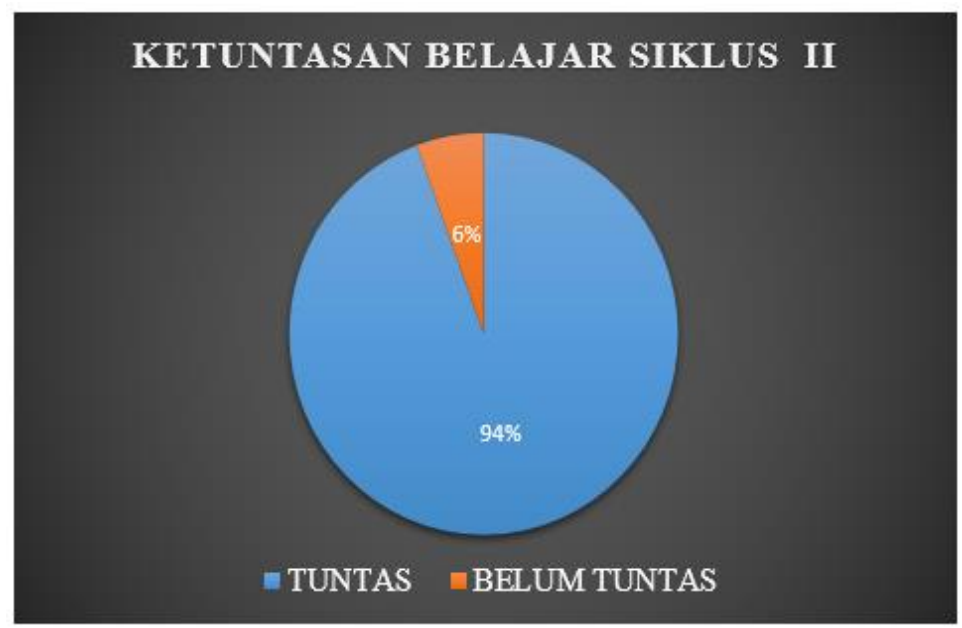

\section{Pembahasan}

Gambar 5. Ketuntasan Belajar Siklus II

Penelitian ini merupakan upaya membantu siswa meningkatkan prestasi belajar siswa kelas XI Teknik Komputer Jaringan 2 SMK Negeri 1 Bangil Kabupaten Pasuruan tentang menghitung luas permukaan dan volume bangun ruang menggunakan model pembelajaran tipe Two Stay Two Stray. (Elly Lulunurjenah: 2012) penelitian dengan judul "Penerapan Model Pembelajaran Koopertif Tipe Two Stay Two Stray (TS-TS) Untuk Materi Gelombang Elektromagnetik Bagi Siswa Kelas X Semester 2 Pada SMAN 4 Palangka Raya Tahun Ajaran 2011/1012", dengan hasil penelitian menunjukkan bahwa tes hasil belajar kelas yang diteliti menunjukkan peningkatan, sehingga secara klasikal juga dikatakan tuntas. Senada dengan (Jupri: 2010) penelitian dengan judul "Penerapan Model Pembelajaran Kooperatif Tipe Two Stay - Two Stray (TS-TS) Untuk Meningkatkan Motivasi dan Hasil Belajar Peserta Didik Materi Pokok Segi Empat Kelas VII c MTs Taqwal Ilah Tembalang Tahun Pelajaran 2009/2010". Untuk merealisasikan usaha tersebut penelitian dilakukan 2 siklus yang terdiri dari 4 komponen yaitu : perencanaan tindakan, pelaksanaan tindakan, observasi, dan refleksi. Setiap pelaksanaan tindakan, peneliti melakukan berbagai langkah sesuai dengan rencana perbaikan pembelajaran. (1) Pada siklus I, guru berupaya mengaktifkan siswa dalam proses pembelajaran dengan menggunakan model pembelajaran tipe Two Stay Two Stray, membimbing siswa mengerjakan lembar kerja. Hal ini dilakukan dengan tujuan agar ada kemauan untuk menemukan sendiri tentang materi menentukan luas permukaan dan volume bangun ruang. Setelah diadakan tes hasil belajar dari 36 siswa melalui tes tertulis diperoleh data yaitu 26 siswa $(72 \%)$ dari keseluruhan siswa sudah mendapatkan prestasi belajar diatas nilai ketuntasan dan 10 siswa $(28 \%$ ) belum mencapai nilai ketuntasan (tuntas yaitu nilai $\geq 70$ ) dengan rata-rata kelas 73,89. (2) Pada Siklus II, diawali dengan pendahuluan, pelaksanaan pembelajaran dimulai dengan mengucapkan salam, berdoa, presensi kelas oleh peneliti sebagai guru kemudian menjelaskan tujuan pembelajaran dan mengingatkan cara penilaian yang akan digunakan. Memberikan apersepsi dengan cara mengaitkan materi pelajaran dengan contoh kehidupan sehari-hari. Motivasi dilakukan peneliti untuk memberikan semangat dalam pembelajaran pertemuan ini dan menjelaskan langkah-langkah kegiatan pembelajaran. Pada kegiatan Inti, peneliti menjelaskan singkat materi tentang luas permukaan dan volume bangun ruang dari buku sumber. Setelah itu guru membagi siswa menjadi 9 (sembilan) kelompok yang masingmasing beranggotakan 4 siswa. Kemudian siswa diminta berkumpul dengan kelompoknya masing-masing. Setelah itu guru membagikan LKS kepada setiap kelompok ,kemudian meminta siswa untuk mengidentifikasi dan memecahkan permasalahan yang ada. Setelah selesai mendiskusikan persoalan yang ada di LKS, dua siswa dari masing-masing kelompok meninggalkan kelompoknya untuk bertamu ke kelompok lain. Sedangkan siswa yang tinggal 
dalam kelompok bertugas menyampaikan hasil kerja mereka kepada siswa yang datang mengunjungi kelompoknnya. Setelah memperoleh informasi dari siswa yang tinggal, siswa mohon diri untuk kembali ke kelompok masing-masing dan melaporkan hasil kerjanya serta mencocokkan dan membahasnya. Selanjutnya guru meminta salah satu kelompok untuk mempresentasikan hasil diskusinya sementara kelompok lain menanggapi. Peningkatan hasil belajar dalam penelitian ini sesuai dengan penelitian yang mengatakan bahwa pembelajaran kooperatif tipe Two Stay Two Stray selain dapat meningkatkan prestasi belajar kognitif siswa juga dapat meningkatkan motivasi dan hasil belajar siswa (Fitriyah: 2012: 133). Dari tes hasil belajar pada siklus II yang dilaksanakan pada tanggal 23 Oktober 2013 diperoleh 34 siswa $(94,4$ $\%$ ) mendapat nilai $\geq 70$ dinyatakan tuntas, dan 2 siswa (5,6\%) mendapat nilai $\leq 70$ dinyatakan belum tuntas dengan rata-rata kelas 82,22 . Melihat ketuntasan dan rata-rata kelas meningkat secara signifikan sehingga siklus III tidak perlu diadakan. (3) Dengan demikian penggunaan model pembelajaran tipe Two Stay Two Stray, dapat meningkatkan prestasi belajar menghitung luas permukaan dan volume bangun ruang siswa kelas XI Teknik Komputer Jaringan 2 SMK Negeri 1 Bangil. Melihat dari nilai hasil belajar, ketuntasan dan rata-rata nilai kelas pada siklus I dan siklus II, maka dengan penggunaan model pembelajaran kooeratif tipe Two Stay Two Stray sangat efektif untuk meningkatkan kemampuan siswa pada pembelajaran matematika. Perbandingan peningkatan itu bisa ditunjukkan dengan gambar 6 berikut ini.

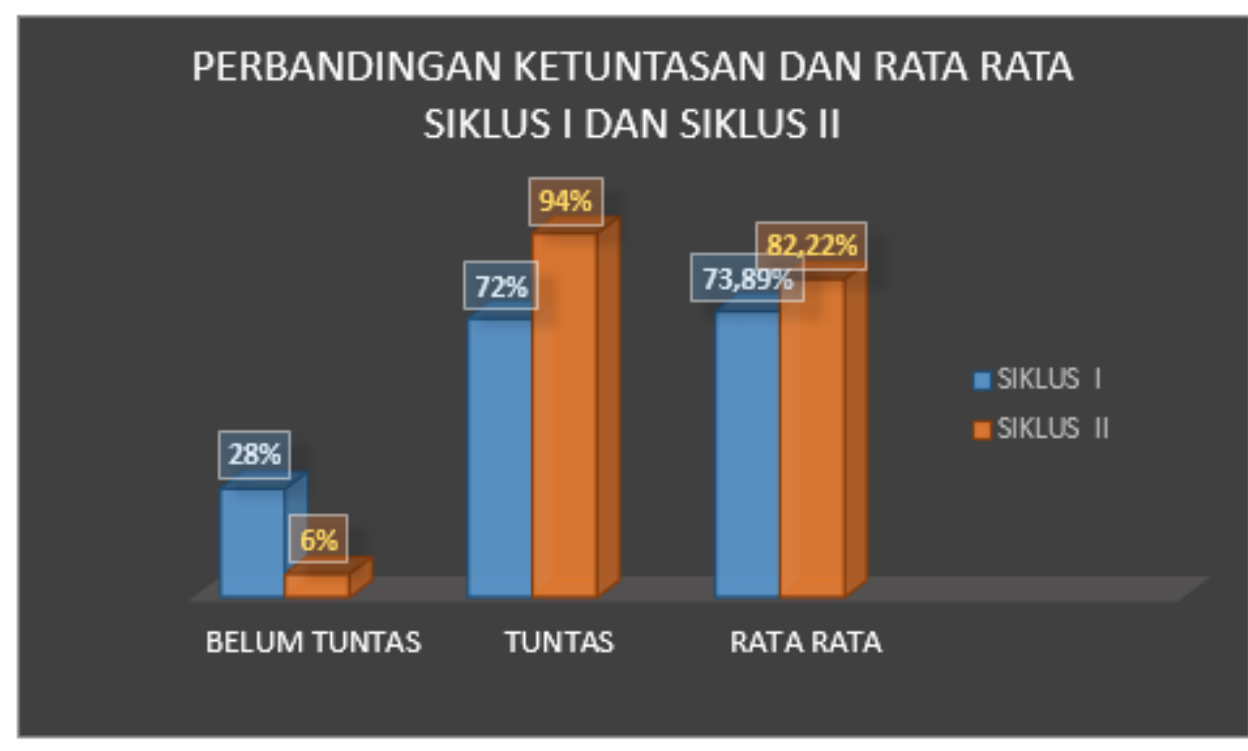

Gambar 6. Perbandingan Ketuntasan dan Rata-rata Siklus I dan Siklus II

\section{KESIMPULAN}

Berdasarkan analisis data mengenai penerapan model pembelajaran tipe Two Stay Two Stray dapat disimpulkan sebagai berikut:

(1) Penerapan model pembelajaran kooperatif tipe Two Stay Two Stray dimulai dengan guru menyampaikan materi secara garis besar dengan tujuan memberikan informasi awal pada siswa tentang materi yang akan dipelajari. Kemudian dilakukan pembentukan kelompok secara heterogen yang terdiri dari 4 siswa. Setelah semua siswa berkumpul dengan kelompoknya masing-masing, guru memberikan permasalahan yang ada di LKS untuk didiskusikan secara berkelompok. Jika diskusi kelompok sudah selesai, 2 siswa dari masing-masing kelompok berpencar untuk bertamu ke kelompok lain guna mendapatkan informasi, sedangkan siswa yang tinggal di kelompok bertugas memberikan informasi, dan anggota yang bertamu diberikan kesempatan untuk menanggapi informasi tersebut. Setiap anggota kelompok saling berbagi informasi yang berkaitan dengan permasalahan yang ada di LKS. Setelah diskusi selesai, anggota yang bertamu kembali ke kelompok asal untuk mencocokkan dan mendiskusikan kembali hasil kerja mereka. Langkah selanjutnya guru meminta perwakilan kelompok untuk mempresentasikan hasil diskusi kelompoknya. 
(2) Terdapat peningkatan prestasi hasil belajar dari siklus I dan siklus II yang ditentukan berdasarkan ketuntasan dan nilai rata-rata kelas XI Teknik Komputer Jaringan 2 SMK Negeri 1 Bangil yang telah dicapai oleh siswa dalam proses pembelajaran. Ini menunjukkan bahwa pembelajaran kooperatif tipe Two Stay Two Stray sangat efektif untuk peningkatan prestasi belajar dan aktifitas siswa.

(3) Respon siswa menunjukkan bahwa siswa berminat terhadap pembelajaran dengan penerapan model pembelajaran kooperatif tipe Two Stay Two Stray dengan kategori sangat baik.

(4) Dengan demikian diharapkan para guru pengajar mata pelajaran di kelas mampu berinovasi dalam melaksanakan pembelajaran dengan meninggalkan gaya mengajar yang selama ini searah dari guru ke siswa. Model pembelajaran kooperatif tipe Two Stay Two Stray menjadi salah satu alternatif pembelajaran ang bisa digunakan.

\section{DAFTAR PUSTAKA}

Arikunto, S. (2013). Prosedur Penelitian Suatu Pendekatan Praktik. Jakarta: PT. Rineka Cipta. Depdiknas. (2007). Buku Saku Kurikulum Tingkat Satuan Pendidikan Sekolah Menengah Pertama. Jakarta: Depdiknas

Elly Lulunurjennah (2012), "Penerapan Model Pembelajaran Kooperatif Tipe Two Stay Two Stay (TS-TS) Untuk Materi Gelombang Elektromagneti Bagi Siswa Kelas X Semester 2 Pada SMAN 4 Palangka Raya", Skripsi, STAIN.

Fitriyah. (2012). Efektivitas Two Stay Two Stray terhadap Aktivitas dan Hasil Belajar Siswa. Unnes Journal of Biology Education 1(2).

Ika Berdiati. (2010). Model Pembelajaran Tipe Two Stay Two Stray. www.kajianpustaka.com

Kasmina, dan Asmaatul Kusna, (2012). Matematika SMK dan MAK Kelas XII. Jakarta: Erlangga.

Lie, Anita. (2005). Cooperative Learning: Mempraktikkan Cooperative Learning di RuangRuang Kelas. Jakarta: Gramedia Widiasarana Indonesia.

Slavin. (2009). Educational Psychology and Practice / Pearson

Sudjana, N. (2012). Penilaian Hasil Proses Belajar Mengajar. Bandung: PT. Remaja Rosdakarya.

Sudjana, Nana. (2005). Dasar-Dasar Proses Belajar Mengajar. Bandung: Sinar Baru.

Sugiyono. (2013). Metode Penelitian Pendidikan Pendekatan Kuantitatif, Kualitatif, dan R\&D. Bandung: Alfabeta.

Trianto. (2010). Mendesain Model Pembelajaran Inovatif-Progresif. Jakarta: Kencana Prenada Media Group. www.person.com

http://penelitiantindakankelas.blogspot.com/2013/03/modelpembelajaran-kooperatiftwo-staytwo-stray.html. $\operatorname{tgl} 13$ mei 2013 